\title{
THE PREVALENCE OF RETRORENAL COLON AMONG COMPUTERIZED TOMOGRAPHY SCANNED PATIENTS
}

\author{
ABDULGHAFOOR S. ABDULKAREEM, MBCHB, FICMS* \\ SALEEM K. MUSALAH, MBCHB, CABBMS** \\ ASAAD S. OMAR, MBCHB, FICS***
}

Submitted 3 July 2020; accepted 24 Dec 2020

\begin{abstract}
Background: percutaneous nephrolithotomy (PCNL) is regarded as the treatment of choice for most renal stones larger than $2 \mathrm{~cm}$. Colon injury is one of the rare and preventable complications during PCNL. The rare and unusual location of the colon behind the kidney (retrorenal colon) is an anatomical predisposing factor and other factors that can result in colon perforation during PCNL.

Aim: To evaluate the prevalence of retrorenal and posterolateral colon and among CT scanned patients.

Patients and methods: one thousand CT scanned patients of all ages and both sexes were included and their CT images were evaluated prospectively at the CT scan center at Azadi Teaching Hospital for the presence of retrorenal colon and the relation of the colon to different parts of the kidney.

Results: In this study, $1000 \mathrm{CT}$ scanned patients of different ages and both sexes were included. There were 522 males and 478 females; their ages ranged from 6 to 85 years. The overall prevalence of retrorenal colon was $7.5 \%$ (6.3\% in males and $8.7 \%$ in females). The prevalence of retro renal colon according to different ages was: at below 10 y was $16 \%, 11$ 20 years $8.3 \%, 21-30$ y $5.9 \%, 31-40$ y $7.2 \%, 41-50$ y $7.2 \%, 51-60$ y $11.2 \%, 61-70$ y $5.8 \% 71-$ $80 \mathrm{y} 7.2 \%$ and at $81-90$ y was $9 \%$, and the differences regarding the ages and sexes were statistically not significant. The lower pole of the left kidney is the most common part involved by the retrorenal colon in $70.6 \%$, while the right lowers pole by $12 \%$, the left middle part by $10.6 \%$, and bilateral lower poles by $6.6 \%$.

Conclusion: Locally, the prevalence of retrorenal colon is within the usual range with no sex or age predominance, and a pre-operative abdominal CT scan (native one) is a diagnostic one and is essential if left lower renal calyx is planned to be targeted to avoid colonic injury.
\end{abstract}

Duhok Med J 2021; 15 (1): 1-10.

Keywords: Colon injury, Retrorenal colon, Percutaneous nephrolithotomy,

\begin{tabular}{|c|c|}
\hline $\begin{array}{l}\text { I he prevalence of retrorenal colon } \\
\text { among computerized tomography } \\
\text { scanned Patients } \\
\text { Urolithiasis is a worldwide problem, and } \\
\text { due to its high prevalence and frequency of } \\
\text { recurrence, more than a single surgical } \\
\text { intervention may be needed. Historically, } \\
\text { large kidney and ureteral stones were } \\
\text { removed through open surgery ( requiring } \\
\text { a large flank incision) has been replaced } \\
\text { by percutaneous nephrolithotomy (PCNL) }\end{array}$ & $\begin{array}{l}\text { a minimally-invasive procedure to remove } \\
\text { stones from the kidney by a small } 1 \mathrm{~cm} \\
\text { puncture wound through the skin, and its } \\
\text { regarded the gold standard procedure for } \\
\text { the treatment of large and complex renal } \\
\text { stones since its application in the early } \\
\text { eighties for its cost-effectiveness, lower } \\
\text { morbidity, shorter operative time and } \\
\text { lower complications. The first successful } \\
\text { renal stone extraction through the } \\
\text { nephrostomy tract was performed in } 1976\end{array}$ \\
\hline
\end{tabular}

** Assistant Prof, Department of the Surgery, College of Medicine, University of Duhok, Kurdistan Region, Iraq

** Lecture, Department of the Surgery, College of Medicine, University of Duhok, Kurdistan Region, Iraq

*** Department of the Surgery, College of Medicine, University of Duhok, Kurdistan Region, Iraq.

Correspondence author: Abdulghafoor S. Abdulkareem, ghafoor1964sulaiman@uod.ac, Mobil+7507714756

https://doi.org/10.31386/dmj.2021.15.1.1 
by Fernström and Johansson ${ }^{1}$.

As with any surgical procedure, there are risks and potential complications that are associated with PCNL, like bleeding, renal collecting system injury, visceral organ injury, pulmonary and thromboembolic complications, extrarenal stone migration, failure to achieve stone-free status, urosepsis, urine leak, and death. The complication rate for PCNL is as high as $83 \%$, and most are minor. Major complications occur at a rate between $1.1 \%-7.0 \%$, including colonic injury, which rarely occurs during PCNL $(0.2 \%-$ $0.8 \%)^{2,3}$.

The colon is among the organs that has a non-constant anatomical relation to the lateral margins of the kidneys (especially to the lower pole of the left kidney), and in rare occasions related to the posterior surfaces (retrorenal colon), and colonic injury is classified as a grade IVa according to the Clavien-Dindo classification system, and it is of great significance, due to its diagnostic challenges as well as severe and fatal complications like septicemia, peritonitis, abscess formation, and nephrocolic or colocutaneous fistula ${ }^{2}$.

In most studies, the most frequent etiology for colon perforation during PCNL is the retrorenal position; additional factors include renal anomalies such as horseshoe kidney, previous intestinal bypass surgery, female sex, elderly, thin patients, and colonic distension. The incidence of colonic injury is greater on the left side and when a more lateral puncture site used $^{4-8}$.

Based on the computerized abdominal tomography (CT) scan, retrorenal colon is usually found in $0.9 \%$ to $16.1 \%$ of the general population. This normal variation is higher in females, in the prone compared to the supine position, in the left rather than the right side, and higher to the lower than upper poles ${ }^{3}$, $9-11$.

The increasing use of multiphasic CT scanners has made it the main imaging preference in the diagnosis of renal stones (including the radiolucent ones) and to determine the stone location within the kidney and thus enables the most suitable track selection and the relationship of the kidney to the surrounding structures, and unsuspected retrorenal colon, so it will alert the endo-urologist to such anatomic colonic variant and helps in the planning of an approach that will avoid a potentially serious colonic complication ${ }^{5,12}$.

Supine native CT is not accurate to plan PCNL access in the prone position. The prone decubitus is associated with more potential organ injuries in the upper pole. In supine, the kidney situates deeper in the abdomen, but the access angle is wider than in prone ${ }^{7}$.

Aim: To study the prevalence of retrorenal colon position among CT scanned patients locally.

\section{PATIENTS AND METHODS:}

A prospective cross-sectional study in the main CT scan center of the radiology department at Azadi-Teaching Hospital in Duhok province/ Iraq was done from September 2019 to May 2020. All patients of all ages and both sexes who were subjected to abdominal CT scan imaging for any indication were included in the study and supine position only after giving consent. CT scans were carried out using 64- and 16-detector CT devices (Philips, Eindhoven, The Netherlands). The dose 
parameters for CT were chosen as 250 $\mathrm{mAS}$ and $120 \mathrm{kV}$. The pitch value was 0.92 ; rotation time was $0.75 \mathrm{~s}$, and the collimation was 6490.625 . The evaluations were carried out on the axial reconstructed images at the workstation. Besides the axial plane, reformatted images on the coronal and sagittal planes were also used. An evaluation was performed using a workstation (View Pro$\mathrm{X}$ version3.0, Rogan-Delft, Veenendaal, The Netherlands) on multi-planar reconstructed images. Any patients with congenital renal anomaly, spinal deformity, ascites, or large abdominal pathology detected in CT scan were excluded from the study.

The anatomic relation of the colon to different levels of both kidneys was evaluated in relation to different age groups, both sexes, and the presence of congenital or acquired pathologies. Retrorenal colon is regarded as partial when any part of the colon is seen crossing the imaginary horizontal line between the posterior surfaces of both kidneys, and a complete one when part of the colon is located behind the kidney and totally separates the kidney from the posterior abdominal wall (fig 1). Fisher exact test was used to evaluate the difference significance between age groups and sexes.

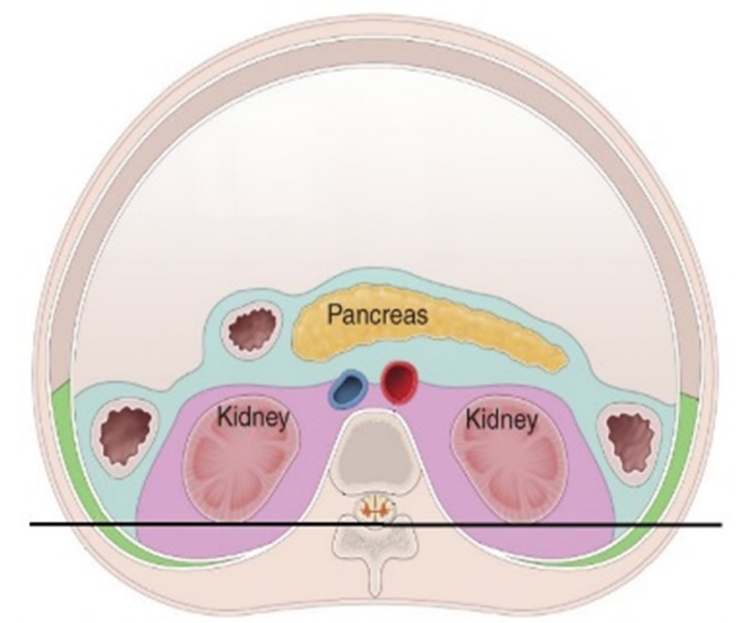

Figure (1): The imaginary line between the posterior surfaces of both kidneys to mark the retrorenal colon position

\section{RESULTS:}

In this study, 1000 patients of different ages and both sexes underwent CT scans for different urological and non-urological conditions. There were 522 males and 478 females, and their ages ranged from 6 to 85 years.

The overall prevalence of retrorenal colon was $7.5 \%(6.3 \%$ in males and $8.7 \%$ in females). The prevalence of retro renal colon according to different ages was: below 10 y was $16 \%, 11-20$ years $8.3 \%$, $21-30$ y $5.9 \%, 31-40$ y $7.2 \%, 41-50$ y $7.2 \%, 51-60 y 11.2 \%, 61-70$ y $5.8 \%$ 71$80 \mathrm{y} 7.2 \%$ and at $81-90 \mathrm{y}$ was $9 \%$. The highest rate of retrorenal colon seen in females in the age group of 51-60 years $(6.4 \%)$, and the differences regarding the ages and sexes were statistically nonsignificant (Table 1). The lower pole of the left kidney was the commonest part involved by the retrorenal colon in $70.6 \%$, while the right lower pole by $12 \%$, the left middle part by $10.6 \%$, and bilateral lower poles by $6.6 \%$. partial retrorenal colon in $71(94.6 \%)$ and complete one in $4(5.3 \%)$ (Table 2). 


\begin{tabular}{|c|c|c|c|c|c|c|c|c|c|}
\hline \multicolumn{10}{|c|}{ THE PREVALENCE OF RETRORENAL COLON AMONG COMPUTERIZED } \\
\hline Table 1: d & stribut & on of ret & orenal color & amo & g scann & d pa & ents in $\mathrm{r}$ & ard to & age and sex \\
\hline \multirow{4}{*}{$\begin{array}{l}\text { Scanned } \\
\text { ages group }\end{array}$} & \multirow[t]{4}{*}{$\mathbf{N}$} & \multirow{2}{*}{\multicolumn{2}{|c|}{$\begin{array}{c}\text { Scanned patients } \\
\text { sex }\end{array}$}} & \multirow{2}{*}{\multicolumn{4}{|c|}{$\begin{array}{l}\text { Sex related retrorenal } \\
\text { colon* }\end{array}$}} & \multicolumn{2}{|c|}{ Retrorenal colon } \\
\hline & & & & & & & & \multirow[t]{3}{*}{$\mathbf{N}$} & \multirow[t]{3}{*}{$\%$} \\
\hline & & \multirow[t]{2}{*}{ Male } & \multirow[t]{2}{*}{ Female } & \multicolumn{2}{|c|}{ Male } & \multicolumn{2}{|c|}{ Female } & & \\
\hline & & & & No & $\%$ & No & $\%$ & & \\
\hline $6-10$ & 6 & 2 & 4 & 0 & 0 & 1 & 16 & 1 & 16 \\
\hline $11-20$ & 84 & 50 & 34 & 5 & 5.9 & 2 & 2.3 & 7 & 8.3 \\
\hline $21-30$ & 184 & 96 & 88 & 5 & 2.7 & 6 & 3.2 & 11 & 5.9 \\
\hline $31-40$ & 194 & 94 & 100 & 7 & 3.6 & 7 & 3.6 & 14 & 7.2 \\
\hline $41-50$ & 206 & 117 & 89 & 5 & 2.4 & 10 & 4.8 & 15 & 7.2 \\
\hline $51-60$ & 124 & 64 & 60 & 6 & 4.8 & 8 & 6.4 & 14 & 11.2 \\
\hline $61-70$ & 136 & 74 & 62 & 3 & 2.2 & 5 & 3.6 & 8 & 5.8 \\
\hline $71-80$ & 55 & 22 & 33 & 2 & 3.6 & 2 & 3.6 & 4 & 7.2 \\
\hline $81-90$ & 11 & 3 & 8 & 0 & 0 & 1 & 9 & 1 & 9 \\
\hline Total & 1000 & 522 & 478 & 33 & $6.3 \%$ & 42 & $8.7 \%$ & 75 & $7.5 \%$ \\
\hline
\end{tabular}

* $\mathrm{P}=0.847$ (based on Fisher's exact test

\begin{tabular}{lcccccccc}
\hline \multicolumn{6}{c}{ Table 2: distribution of retrorenal colon in relation to the kidney parts. } \\
\hline \multicolumn{7}{c}{ Right kidney } & \multicolumn{3}{c}{ Left kidney } & Bilateral & Partial & Complete \\
\hline Upper & Middle & Lower & Upper & Middle & Lower & Lower poles \\
0 & 0 & 9 & 0 & 8 & 53 & 5 & 71 & 4 \\
\hline
\end{tabular}

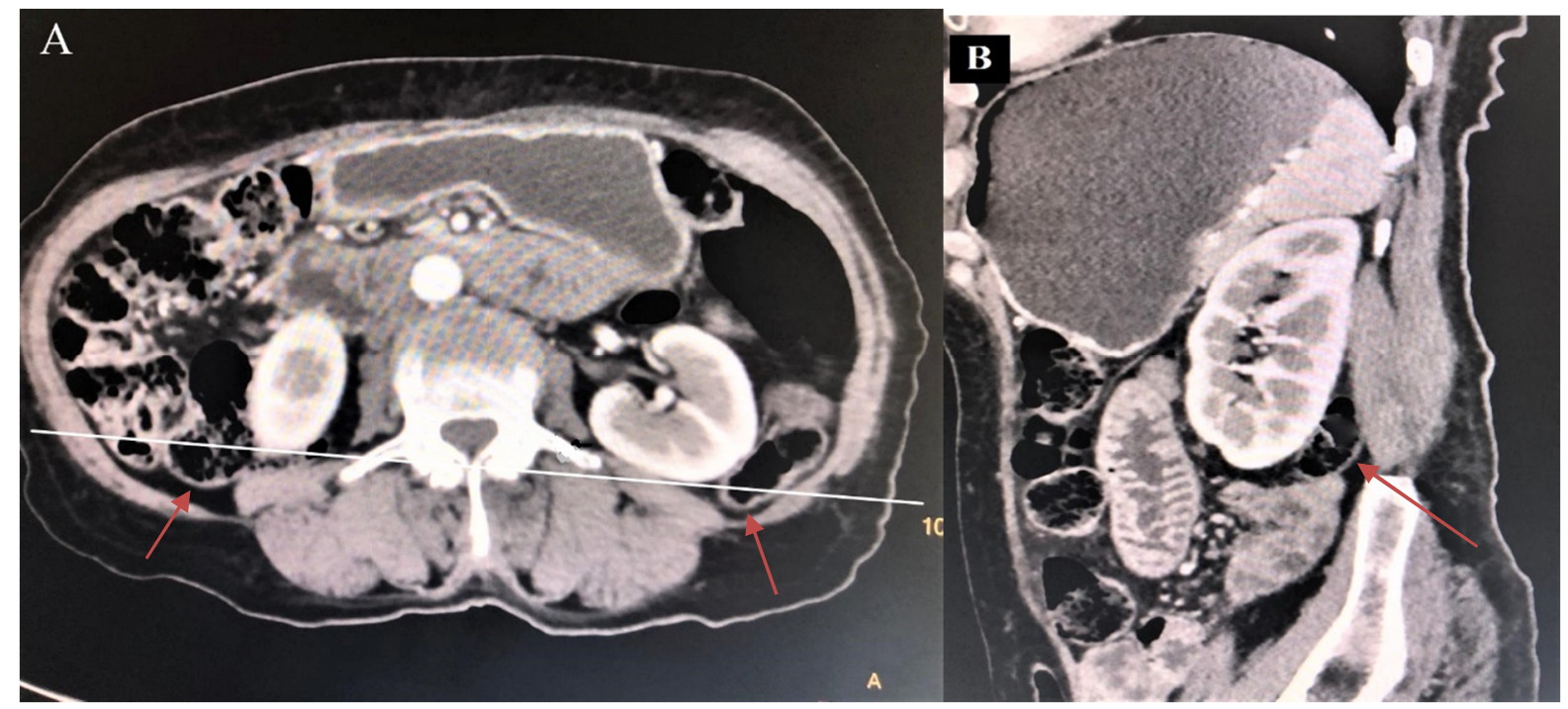

Figure 2: CT images of retrorenal colon: A, Cross section CT shows the bilateral posterior location of the colon to the line drawn between the posterior surfaces of both kidneys. B, Sagittal section CT image shows the posterior position of the colon to the lower pole of the kidney. 


\section{DISCUSSION:}

The success of any surgical procedure depends on the effectiveness of dealing with the pathology and with minimal morbidity. As there is no single surgical procedure without possible complications, the ones with the least complications will generally gain acceptance. Since the introduction of percutaneous renal surgery forty years ago, the continuous evolvement of the procedure is taken place through miniaturizing the standard size of 24-30 Fr to the mini and ultra-mini one ${ }^{11-13}$ Fr to minimize the renal tissue damage, the replacement of fluoroscopy by ultrasound to access the pelvicalyceal system to minimize the hazard of radiation exposure to the patient and operating personnel and the patient positioning during the procedure from prone to supine or oblique to ease the patient position for less anesthetic complications, to shorten the operation time and to decrease the chance of colonic injury as the colon changes its relation to the kidney with patient position $^{13,14}$.

Despite the invasiveness of the PCNL procedure the colonic injury is a rare $(0.2 \%)$ but it is a serious one and every effort should be made to avoid colonic injury.

In this study, we tried to evaluate the relation of the ascending and descending colon (hepatic or splenic flexure) to the right and left kidney, and the prevalence of the unusual position of the colon behind the kidney among CT scanned patients to avoid its injury during percutaneous renal procedures or biopsy. The overall prevalence of retrorenal colon in the general population shows to be variable in regard to age and sex in different studies, from $0.6 \%$ to $16.1 \%{ }^{9},{ }^{15-17}$.

Generally, in the young group, the position of the colon is similar in both genders, with the increase in age; the colon is displaced anteriorly in men, whereas it kept its lateral position in women. The retrocolon in our study was more prevalent in females than males ( $8.7 \%$ vs. $6.3 \%)$, but it was statistically not significant. Two factors have determined this situation, first colon ontogenesis, a long mesocolon, allowing the colon to pass behind the kidneys, and second, the mechanical factor of increasing peri-renal fat with aging may be a limiting factor for retrorenal colon displacement ${ }^{15}, 18,19$.

According to different studies, including ours, the lower pole of the left kidney was the commonest part of the kidney involved by the retrorenal colon position, so the exclusion of the retrorenal colon is essential in any patient when the left kidney is accessed through its lower pole. Boom et al in reviewing $\mathrm{CT}$ images of his PCNL patients showed that the left colon was posterior in $16.1 \%$ of cases, and the right colon was posterior in $9 \%$ of cases at the level of the lower pole ${ }^{9},{ }^{12}$.

Although the prone position CT scan has not been done in this study, other studies showed the prevalence of reterorenal colon in prone position is five folds more than in supine position $10 \%$ and $1.9 \%$ respectively as prone positioning results in a more gasdistended colon, so the trend now is toward changing the patient position during PCNL to supine one to decrease the positional retrorenal position and hence decreasing the possibility of colonic injury ${ }^{10,17}$. 
In the other hand, in a meta-analysis of the supine vs. prone PCNL, the incidence of colon injury in the prone position was estimated to be $0.2-0.5 \%$. The rate of colonic injury in supine PCNL from comparative studies was $\approx 0.5 \%$, similar to the rate in other reports of prone PCNL, concluding that supine PCNL does not increase the risk of colonic injury. In contrast, Marchini et al. ${ }^{8}$ concluded that supine CT is not suitable for prone PCNL as the kidneys are located deeper, resulting in a higher chance for colonic injury $8,16,20,21$.

In conclusion, a locally retrorenal colon is a rare anatomical position but within the normal range, and low-dose and costeffective CT should be performed to avoid colon injuries as it provides an excellent representation of the kidney anatomy and other risk factors predisposing to colonic injury while planning a PCNL intervention. A prone position CT study is needed because PCNL is usually performed in the prone position.

\section{REFERENCES:}

1. Patel SR, Nakada SY. The Modern History and Evolution of Percutaneous Nephrolithotomy. J Endourol. 2015;29 (2):153-7. https://doi.org/10.1089/end.2014.0287

2. Michel MS, Trojan L, Rassweiler JJ. Complications in percutaneous nephrolithotomy. Eur Urol. 2007;51(4):899-906. https://doi.org/10.1016/j.eururo.2006. 10.020

3. Zare MA, Darabi MR, Shakiba B, Mahtaj LG. Colonic perforation during percutaneous nephrolithotomy:
An 18-year experience. CUAJ. 2014;8(5-6):323-6.

https://www.ncbi.nlm.nih.gov/pmc/art icles/PMC4039595/

4. El-Nahas, A.R., Shokeir, A.A., ElAssmy, A.M., Shoma, A.M., Eraky, I., El-Kenawy, M.R., El-Kappany, H.A., Colonic perforation during percutaneous nephrolithotomy: study of risk factors. Urology. 2006; 67(5):937-941. https://doi.org/10.1016/j.urology.2005 .11 .025

5. Daughtry JD, Rodan BA, Bean WJ. Avoiding Bowel Perforation During Percutaneous Nephrolithotomy in Patients with Renal Anomalies. J Endourol. 1987;1(3):173-6. https://www.liebertpub.com/doi/10.10 89/end.1987.1.173

6. Gadzhiev N, Malkhasyan V, Akopyan G, Petrov S, Jefferson F, Okhunov Z. Percutaneous nephrolithotomy for staghorn calculi: Troubleshooting and managing complications. Asian J Urol. 2019;7(2):139-48. https://www.sciencedirect.com/scienc e/article/pii/S2214388219301031

7. Öztürk H.Treatment of Colonic Injury During Percutaneous Nephrolithotomy. Rev Urol. 2015;17(3):194-201. https://www.ncbi.nlm.nih.gov/pmc/art icles/PMC4633665/

8. Marchini GS, Berto FC, Vicentini FC, Shan CJ, Srougi M, Mazzucchi E. Preoperative Planning with Noncontrast Computed Tomography in the Prone and Supine Position for Percutaneous Nephrolithotomy: A Practical Overview. J Endour. 
2015;29(1)

https://doi.org/10.1089/end.2014.0299

9. Boon JM, Shinners B, Meiring JH. Variations of the position of the colon as applied to percutaneous nephrostomy. Surg Radiol Anat. 2002;23:421-5.

https://link.springer.com/article/10.10 07/s00276-001-0421-3

10. Hopper KD, Sherman JL, Luethke JM, Ghaed N. The retrorenal colon in the supine and prone patient. Radiology. 1987;162(2):443-6. https://doi.org/10.1148/radiology.162. 2.3797658

11. Stefanos K, Athanasios P, Christian B, Stylianos K, Faruquz Zaman F, et al. Colon perforation during percutaneous renal surgery: a 10-year experience in a single endourology centre. Urol Res. 2012; 40,263-8. https://doi.org/10.1007/s00240-0120464-4

12. Balasar M, Kandemir A, Poyraz N, Unal Y, Ozturk A. Incidence of retrorenal colon during percutaneous nephrolithotomy. Int Braz J Urol. 2015; 41(2):274-8.

https://www.intbrazjurol.com.br/pdf/v ol4050/Vol41_n2_2015.pdf \#page $=90$

13. Lojanapiwat B. The ideal puncture approach for PCNL: Fluoroscopy, ultrasound or endoscopy? Indian J Urol. 2013;29(3):208-13. https://www.ncbi.nlm.nih.gov/pmc/art icles/PMC3783701/

14. Agrawal MS, Agarwal K, Jindal T, Sharma M. Ultra-mini-percutaneous nephrolithotomy: A minimallyinvasive option for percutaneous stone removal. Indian J Urol. 2016;32(2):132-6. https://www.ncbi.nlm.nih.gov/pmc/art icles/PMC4831502/

15. Hadar H, Gadoth N. Positional relations of colon and kidney determined by perirenal fat. AJR. 1984;143(4):773-6.

https://www.ajronline.org/doi/abs/10.2 214/ajr.143.4.773

16. Balasar M, Kandemir A, Poyraz N, Unal Y, Ozturk A. Incidence of retrorenal colon during percutaneous nephrolithotomy. Int Braz J Urol. 2015;41(2):274-8.

https://www.scielo.br/scielo.php?scrip $\mathrm{t}=$ sci_arttext\&pid=S1677-

55382015000200274

17. Sharma G1, Jangid DK, Yadav SS, Mathur R, Tomar V. Retro-renal colon: role in percutaneous access. Urolithiasis. 2015;43(2):171-5. https:/www.ncbi.nlm.nih.gov/pubmed $/ 25344467$

18. Sherman JL, Hopper KD, Green AJ, Johns TT. The retrorenal colon on computed tomography: a normal variant. J Comput Assist Tomogr. 1985;9(2):339-41.

https://journals.lww.com/jcat/toc/1985 103000

19. Faure JP, Richer P, Chansigaud JP, Scepi M, Irani J,FerrieJC, Kamina P. A prospective radiological anatomical study of the variations of the position of the colon in the left pararenal space. Surg Rad Anat. 2001;23(5):335-6. https://link.springer.com/article/10.10 07/s00276-001-0335-0

20. Wu P., Wang L., Wang K. Supine versus prone position in percutaneous nephrolithotomy for kidney calculi: a meta-analysis. Int Urol Nephro. 2011;43(1):67-77. 
https://link.springer.com/article/10.10

07/s11255-010-9801-0

21. Nour HH, Kamal AM, Ghobashi SE, Zayed AS, Rushdy MM, El-Baz AG, Kamel AI, El-Leithy T. Percutaneous nephrolithotomy in the supine position: Safety and outcomes in a single-centre experienceHani. Arab J Urol. 2013;11(1):62-7. http://europepmc.org/article/PMC/444 2971 


\section{بوخته}

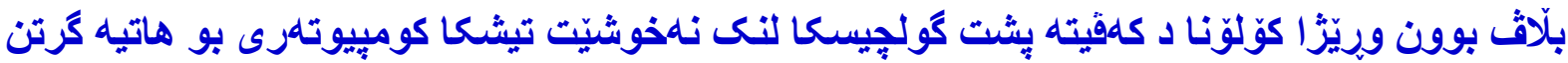

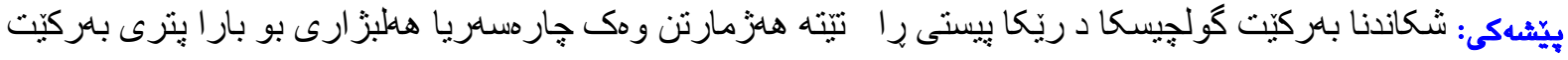

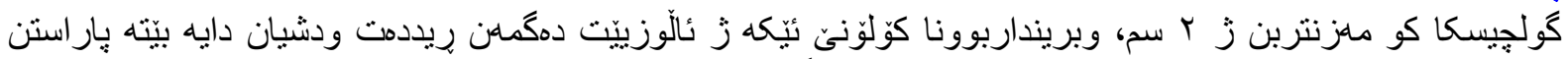

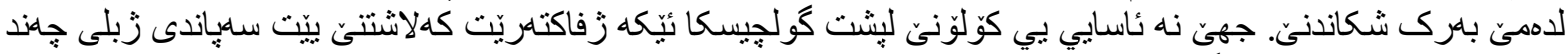

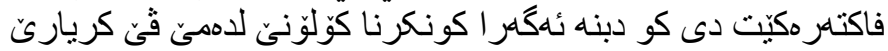

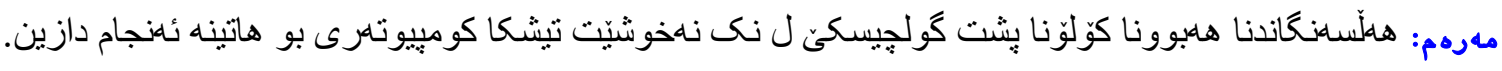

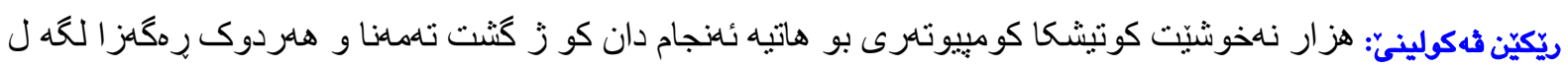

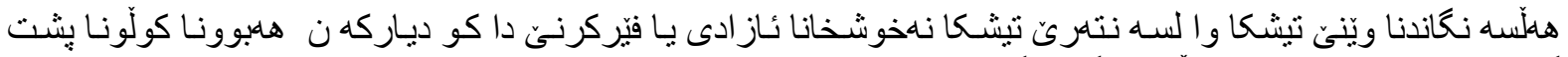

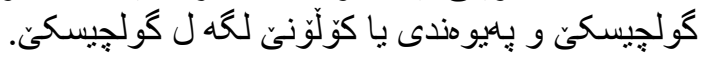

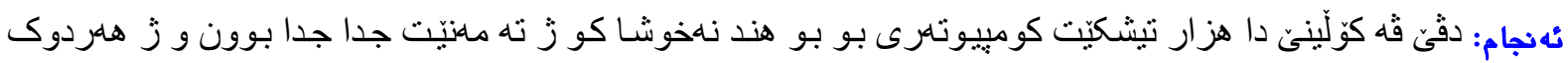

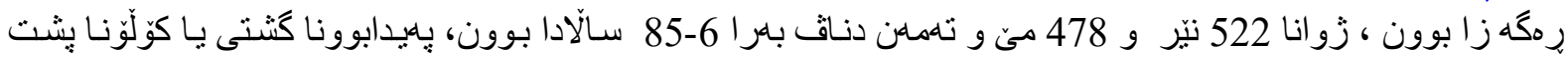

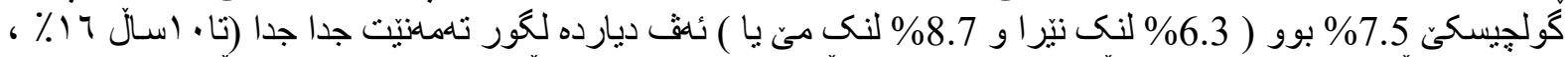

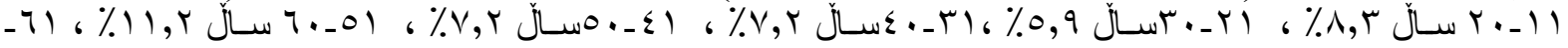

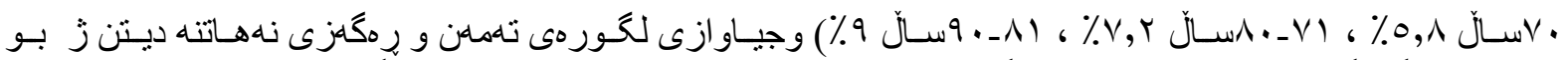

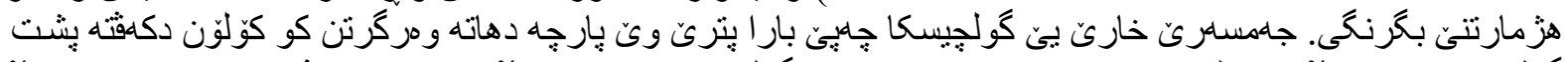

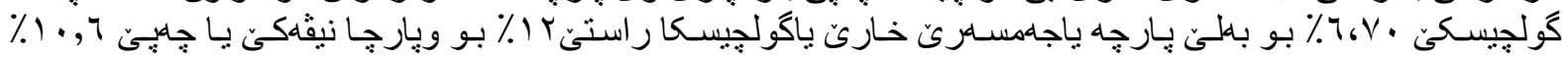

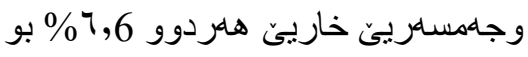

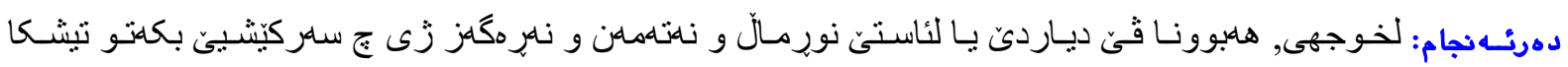

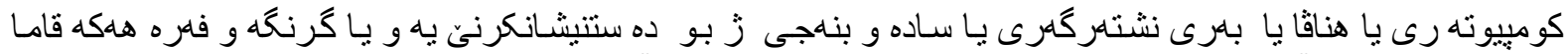

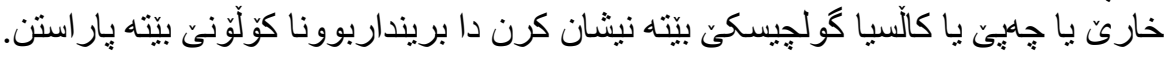




\section{الخلاصة}

معدل إنتشارالقولون خلف الكليوي بفص المفراس

الخلفية والأهداف: إستخراج حصاة الكلية عن طريق الجلد تعتبر الطريقة الحديثة الأمثل لعلاج الحصيات أكبر من

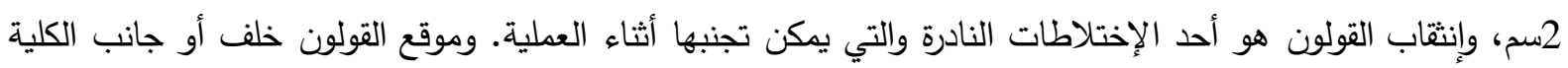

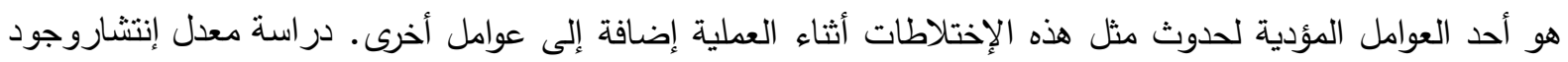

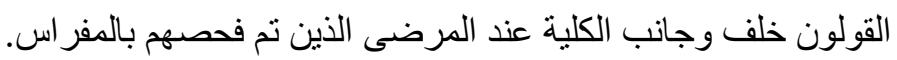

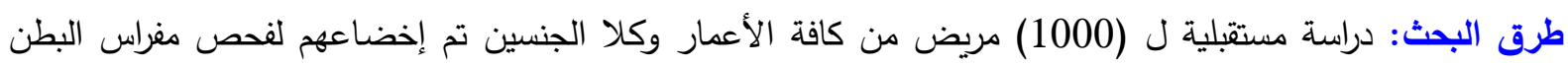
لأسباب مختلفة لدراسة وجود القولون خلف الكلوي وعلاقة القولون بأقسام الكلية في مستشفى آزادي التعليمي بمحافظة

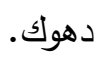

النتائج: العينة التي تم دراستها تضمنت ألف مريض تراوحت أعمارهم من 6-85 سنة ومن كلا الجنسين حيث كان هناك

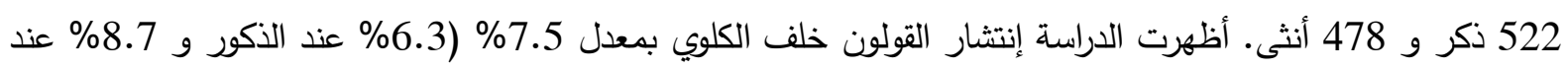

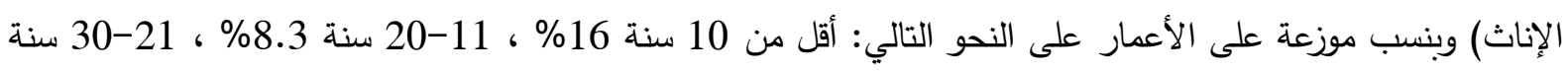

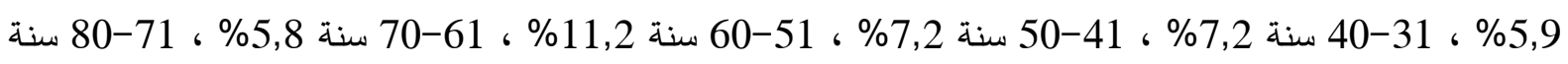

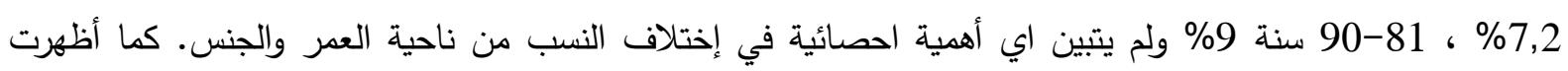

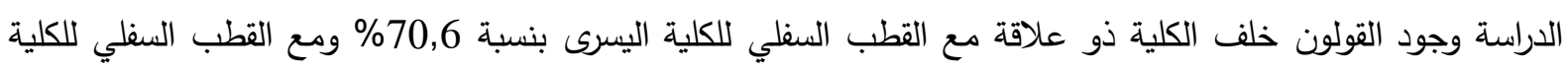
اليمنى بنسبة 12\% والجزء الوسطي للكلية اليسرى بنسبة 10,6\% والقطب السعب السفلي للكليتين في نفس المرضى بنسبة \% 6,6 الاستنتاجات: معدل إنتشار وجود القولون خلف الكلية كانت ضمن المعدلات الإعتيادية عند المرضى محليا ولاتوجد أهمية

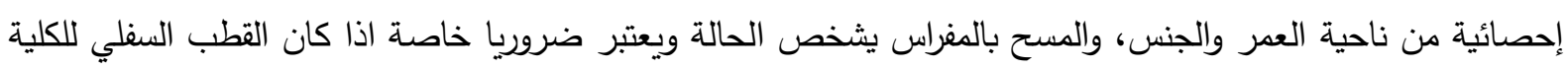
اليسرى ضمن مسلك التداخل الجراحي. 